\title{
Experimental study on the fire performance of straight-line dovetail joints
}

\author{
Jin Zhang ${ }^{1}\left(\mathbb{D} \cdot\right.$ Yixiang $\mathrm{Xu}^{2} \cdot$ Fang $\mathrm{Mei}^{1} \cdot$ Cheng $\mathrm{Li}^{1}$
}

Received: 25 August 2017 / Accepted: 2 December 2017 / Published online: 22 January 2018

(C) The Japan Wood Research Society 2018

\begin{abstract}
To study the fire performance of the common dovetail joint in Chinese ancient architecture, we performed fire exposure and fire resistance tests of straight-line dovetail joints. The fire exposure test shows that the contact part of the dovetail joint was hardly charred because the gap between them is small. In the reference test, the displacement linearly varies with the load when the dovetail joint is fully pressed together. In the fire test, fire retardant coating can improve the fire resistance of the specimen, and its fire protection effect is remarkable. With the increase in load, the fire resistance of specimens obviously decreases. The effect of a tiny $2-4 \mathrm{~mm}$ gap between the tenon and the mortise on heat transfer is notably limited. The load level does not significantly affect the speed of temperature increase.
\end{abstract}

Keywords Dovetail joint $\cdot$ Charring rate $\cdot$ Fire resistance $\cdot$ Cross section temperature

\section{Introduction}

The dovetail joint is one of the major features and a key part of timber structures in Chinese ancient architecture. Its load bearing is extremely complex, and determining its fire performance is important in evaluating the fire performance of ancient timber structures.

Many research studies have been conducted over the years to investigate the fire performance of timber structures. Numerous research results indicate that the wood charring rate is relevant to the density, oxygen permeability, moisture content, thermal flux, specimen size, and atmospheric conditions of the chemical component and various factors $[1,2]$. Eurocode 5 (EC5) states that the charring rate of softwood is inversely proportional to the density [3]. When the notional characteristic density of hardwood is over $450 \mathrm{~kg} / \mathrm{m}^{3}$, the charring rate is $0.55 \mathrm{~mm} / \mathrm{min}$; when the density of hardwood is over $290 \mathrm{~kg} / \mathrm{m}^{3}$, the charring rate is $0.70 \mathrm{~mm} / \mathrm{min}$. Hugi et al. drew different conclusions from an experiment with 12

Jin Zhang

zhangjin0622@139.com

1 Key Laboratory of Concrete and Prestressed Concrete Structures of the Ministry of Education, Southeast University, Nanjing 210096, Jiangsu, China

2 Advanced Manufacturing Research Centre, University of Sheffield, Sheffield S60 5TZ, UK common tree species in Europe and North America (densities of $350-750 \mathrm{~kg} / \mathrm{m}^{3}$ ) and found that the charring rate was closely related to the oxygen permeability of the wood but hardly related to the wood density and wood fiber direction [4]. According to ISO 834 [5], Njankouo et al. experimentally studied the charring rate of Europe softwood and tropical hardwood. The results showed that the wood charring rate was closely relevant to the density and moisture content [6]. According to the experiment, Firmanti et al. found that with the increase in thermal flux, the charring rates of pine, redwood, oak and basswood increased, and the effects of the thermal flux and specimen size on the charring rate were obvious [7]. Babrauskas found that the charring rate of a full-scale timber structure was closely relevant to the building characteristics, the atmospheric conditions of each part and the location of each component, and its values were generally greater than the charring rate under standard test conditions [8].

In terms of the fire resistance of the timber structure connection, Norén tested the fire resistance of a wood-wood-wood nailed joint [9]. By changing the thickness of the side wood, the diameter of the steel nail and the load level, the effect of these factors on the connection were studied. The experiment found that the load level and thickness of the side wood significantly affecting the fire resistance of the connection were significant, whereas the effect of the diameter of the steel nail was small. Peng 
et al. studied the fire resistance of the wood-wood bolted connection, the wood-steel bolted connection with splint plates and the wood-steel bolted connection with slottedin plates and established a finite-element model to compare with the experimental results [10]. They also studied the effect of the wood thickness, bolt diameter, end and edge distance of the bolt and protective measures on the fire resistance of the timber structure connection. Audebert et al. conducted a fire resistance study and numerical analysis on the wood-steel-wood connection of the timber structure, which mainly focused on the temperature distribution of the bolts or dowels in the wood-steel connection subjected to tension paralleled to the grain and the differences between two types of fasteners [11]. These reports studied the fire resistance by loading in the grain direction of the wood. When the load was put perpendicular to the grain, the fire resistance of the connection in the experiment had a duration of more than $1 \mathrm{~h}$, and the final destruction form of the connection was splitting failure along the grain, although the tensile strength of the wood perpendicular to the grain was smaller than that parallel to the grain [12]. The specimens in the above discussion were modern timber structure steel-wood connections. However, few studies about the fire resistance of timber structure mortise and tenon joints have been published.

In recent years, the timber structure architecture in China has been through a recovery phase. The recovery of forestry resources and the increasing number of imported timbers has promoted the timber structure architectural market in China. Some domestic scholars have performed studies on the fire resistance of timber structures. Zhang et al. performed experimental studies and numerical simulations on the fire resistance of wood beams exposed to a three-side fire, and the results showed that the wood density and load level significantly affected the fire resistance of wood beams exposed to a three-side fire $[13,14]$. XU et al. implemented a static stress test of wood beams with lime putty plaster and analyzed its effect on the fire performance of wood beams [15]. These publications are mainly about the fire performance of single beams or column components, whereas studies on the fire performance of dovetail joints are notably rare. Ni et al. conducted a series of standard fire tests on timber structure building components and studied their fire performance, failure mode and fire resistance [16]. Ru et al. performed fire tests of glue-laminated wood member bolted connections. The results showed that the bolt diameter and bolt spacing did not significantly affect the fire performance, whereas increasing the thickness of the side members, decreasing the load level and increasing the connection edge and end distance helped improve the fire performance [17]. However, the objective of their study was the bolted connection with slotted-in plates instead of dovetail joints, which are commonly used in ancient Chinese architecture.
The effect of a gap in the contact part on the mechanical performance of the traditional mortise tenon joint was studied by Ogawa et al. [18]. The results showed that the mechanical performance of the joints gradually decreased with the increase in size of the gap. Kunecky et al. also investigated the effect of the gap on the mechanical performance of dovetail joints and found that small gaps up to $2 \mathrm{~mm}$ in the mortise-tenon contact areas had an insignificant effect on the dovetail performance. However, they may slightly affect the performance of the joint when the gaps reach $5 \mathrm{~mm}$ [19]. Li et al. also studied the mechanical properties of the traditional timber mortise tenon joints, which include the connection stiffness, flexibility, hysteretic model and relationship between the bending moment and the relative rotation [20]. However, the effect of a gap on the fire resistance of the dovetail joint has not been studied.

This paper first investigates the charring rate of a straightline dovetail joint exposed to fire. Then, the fire resistance test of a dovetail joint exposed to a four-side fire was performed, and the effects of different load levels, gap and surface fire prevention measures on the fire resistance were studied. This paper analyzes the cross-section temperature variation of the dovetail joint in fire exposure and fire resistance tests.

\section{Fire exposure test and results}

\section{Test equipment and materials}

The test was performed in the large-scale horizontal test furnace in Southeast University Key Laboratory for Concrete and Prestressed Concrete Structure of the Education Ministry of China. The furnace was $4.0 \mathrm{~m}$ long, $2.5 \mathrm{~m}$ wide and $1.5 \mathrm{~m}$ high. The temperature in the furnace was controlled using four thermocouples and two temperature regulators. The furnace could follow ISO 834 [5] series.

The test used glue-laminated Douglas fir wood with a density at room temperature $\left(20^{\circ} \mathrm{C}\right)$ of $480 \mathrm{~kg} / \mathrm{m}^{3}$, a moisture content of $10.4 \%$, a parallel-to-grain compressive strength of 29.38 MPa, a parallel-to-grain tensile strength of $78.00 \mathrm{MPa}$ and a parallel-to-grain elastic modulus of 10,178 MPa. The wood was supplied by the glue-laminated Douglas fir wood producer. The adhesive was resorcin-modified resin adhesive. Because the fire resistances of glulam and solid timber are parallel [21, 22] and it is difficult to obtain sufficiently large solid timber, the test used the glulam.

$\mathrm{K}$-type sheathed thermocouples made of $\mathrm{NiCr}-\mathrm{Ni}$ were used, and the temperature range fell of the thermocouple is between -200 and $1300{ }^{\circ} \mathrm{C}$. Thermocouple wire was sheathed with the adiabatic materials ceramic wafer.

The heat insulation material was a ceramic fiber acupuncture blanket, which was specified by the fire laboratory. The 
maximum service temperature of the ceramic fiber acupuncture blanket was $1350^{\circ} \mathrm{C}$. With a low heat conductivity coefficient, its heat insulation effect was good.

\section{Specimens}

Four straight-line dovetail joints with identical sizes and wood species were implemented. The joint consisted of two timber parts, which were $400 \mathrm{~mm}$ long, $240 \mathrm{~mm}$ wide and $160 \mathrm{~mm}$ thick. The specimen sizes are shown in Fig. 1, and the numbers are shown in Table 1, where z10, z20 and z30 represent the charring rate test specimens which were under going 10, 20 and $30 \mathrm{~min}$ fire exposure, respectively, zp30 represents the charring rate test specimen with thin film intumescent coating under going $30 \mathrm{~min}$ fire exposure. The coating was brushed three times every $3 \mathrm{~h}$. The coating quantity was $450-500 \mathrm{~g} / \mathrm{m}^{2}$, and the thickness was $1 \mathrm{~mm}$. The resin-based coating expanded and formed dense heat insulation layer.

The tenon narrow, tenon wide, mortise narrow and mortise wide parts are shown in Fig. 1. TN represents the tenon narrow, and TW represents the tenon wide. Similarly, MN denotes the mortise narrow, and MW denotes the mortise wide. As shown in Fig. 2, the gaps are measured between $\mathrm{TN}$ and MN and TW and MW. The mean value of gaps between the tenon and the mortise before the fire exposure is shown in Table 2.
Table 1 List of charring rate specimens

\begin{tabular}{llll}
\hline Specimen & $\begin{array}{l}\text { Protective } \\
\text { coating }\end{array}$ & $\begin{array}{l}\text { Fire exposure time } \\
(\mathrm{min})\end{array}$ & $\begin{array}{l}\text { Number of } \\
\text { specimens }\end{array}$ \\
\hline z10 & No & 10 & 1 \\
z20 & No & 20 & 1 \\
z30 & No & 30 & 1 \\
zp30 & Yes & 30 & 1 \\
\hline
\end{tabular}

\section{Test procedures}

The test used the ISO 834 [5] standard temperature rising curve. In the fire test, both ends of the straight-line dovetail joint were placed on the fireproofing brick, as shown in Fig. 3. The distance from the specimen to the furnace bottom was approximately $1 \mathrm{~m}$, and the connection exposed to fire was $720 \mathrm{~mm}$ long. The exposure to a four-side fire was realized.

First, we heated the specimen in the fire furnace to set the time; then, we cut the fuel gas. When the furnace temperature decreased to $150{ }^{\circ} \mathrm{C}$, the specimen was taken out and was cooled with water. The time elapsed from turning off the burners to extinguishing the fire was about $30 \mathrm{~min}$.
Fig. 1 Detailed drawing of the specimen size of the straightline dovetail joint
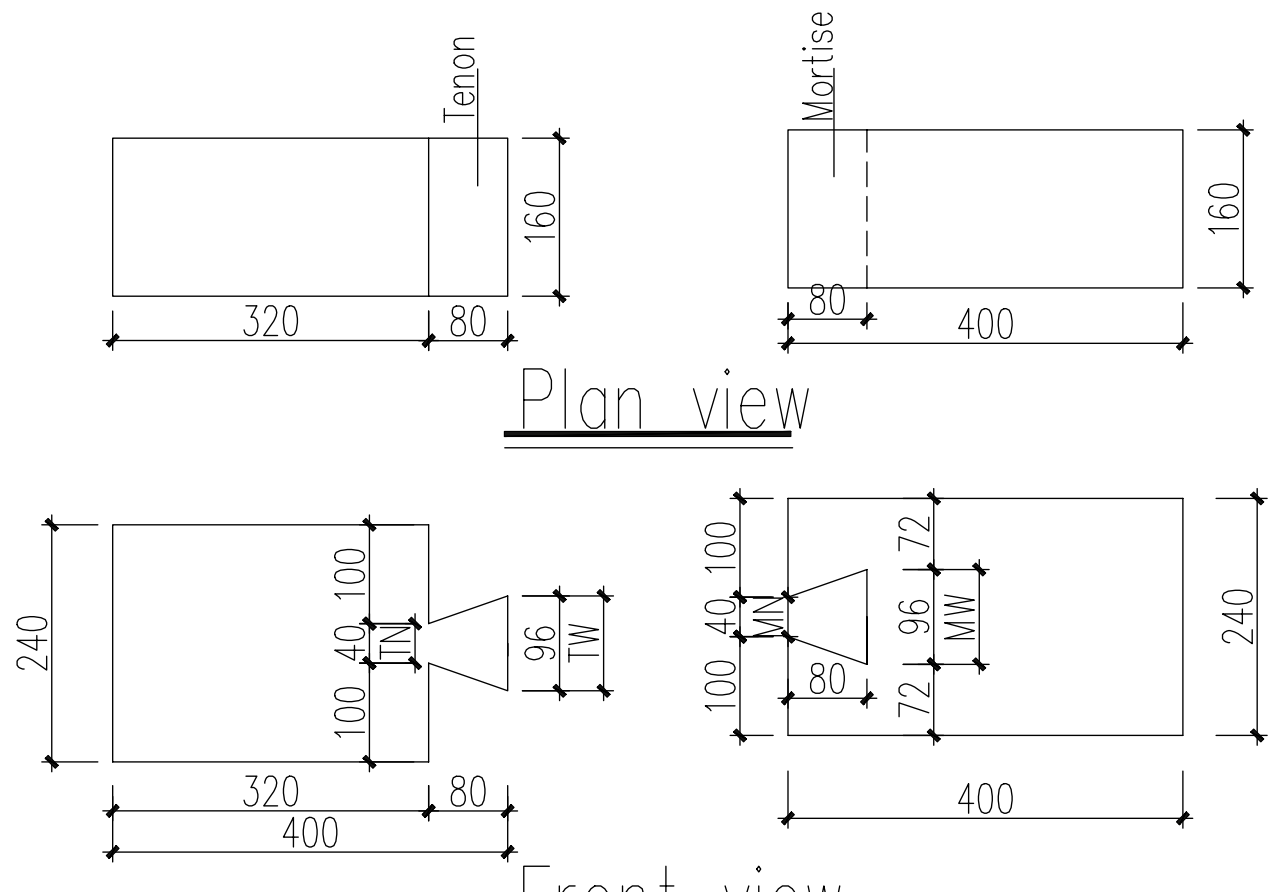

The dimensions in this figure are in millimeters 
Fig. 2 Gaps between tenon and mortise

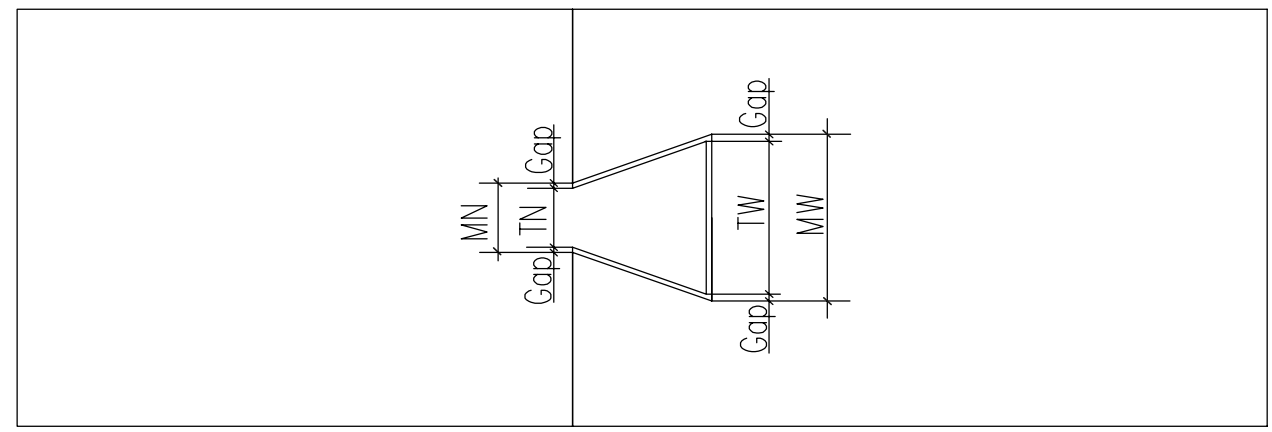

Table 2 Gaps between the straight-line tenon and the mortise

\begin{tabular}{lll}
\hline Specimen & $\begin{array}{l}\text { Gap between TN and MN } \\
(\mathrm{mm})\end{array}$ & $\begin{array}{l}\text { Gap between TW } \\
\text { and MW }(\mathrm{mm})\end{array}$ \\
\hline z10 & 4.0 & 3.2 \\
z20 & 2.1 & 2.2 \\
z30 & 4.1 & 4.0 \\
zp30 & 4.0 & 4.2 \\
\hline
\end{tabular}

$T N$ tenon narrow, $T W$ tenon wide, $M N$ mortise narrow, $M W$ mortise wide

\section{Test results}

The specimens after fire are shown in Fig. 4. After the fire test, the charring layer on the specimen surfaces was knocked off. The cross sectional dimensions of TW, TN, MW and MN were measured to obtain the changes of gaps. And the cross sectional dimensions of the specimen at $200 \mathrm{~mm}$ from both ends was measured to obtain the horizontal and vertical charring rate. Only fire exposure time was used to calculate the charring rate.

Within a few minutes after the fire test began, the fit of the furnace temperature and the ISO 834 [5] standard temperature rising curve is poor, as shown in Fig. 5. This difference has great effects on the charring rate of the specimen. Thus, the charring rate of the specimen requires modification.

This paper modified the charring time, i.e., it applied the effective charring time. Ingberg (1928) introduced the equivalency concept by stating that two fires have equivalent severity if the areas under each time-temperature curve are equal [23]. The formula was given as:

$\int_{0}^{t_{1}} T_{1} \mathrm{~d} t=\int_{0}^{t_{2}} T_{2} \mathrm{~d} t$

where $t_{1}$ is the charring time, $T_{1}$ is the furnace temperature, $t_{2}$ is the effective charring time, $T_{2}$ is the furnace temperature.

This method can be used to solve the effective charring time of each fire exposure test and obtain the converted charring rate. The specimen charring rates and converted charring rates are summarized in Tables 3 and 4 .

Table 4 shows that (1) the horizontal charring rates of the wood component without the fire-retardant coating for different fire times were $0.69,0.70$ and $0.65 \mathrm{~mm} / \mathrm{min}$, all of which are smaller than the vertical charring rates of $0.75,0.73$, and $0.74 \mathrm{~mm} / \mathrm{min}$. (2) The mean horizontal charring rate of the wood component with the fire-retardant coating was $0.55 \mathrm{~mm} / \mathrm{min}$, and the vertical charring
Fig. 3 Specimen layout drawing of the fire exposure test

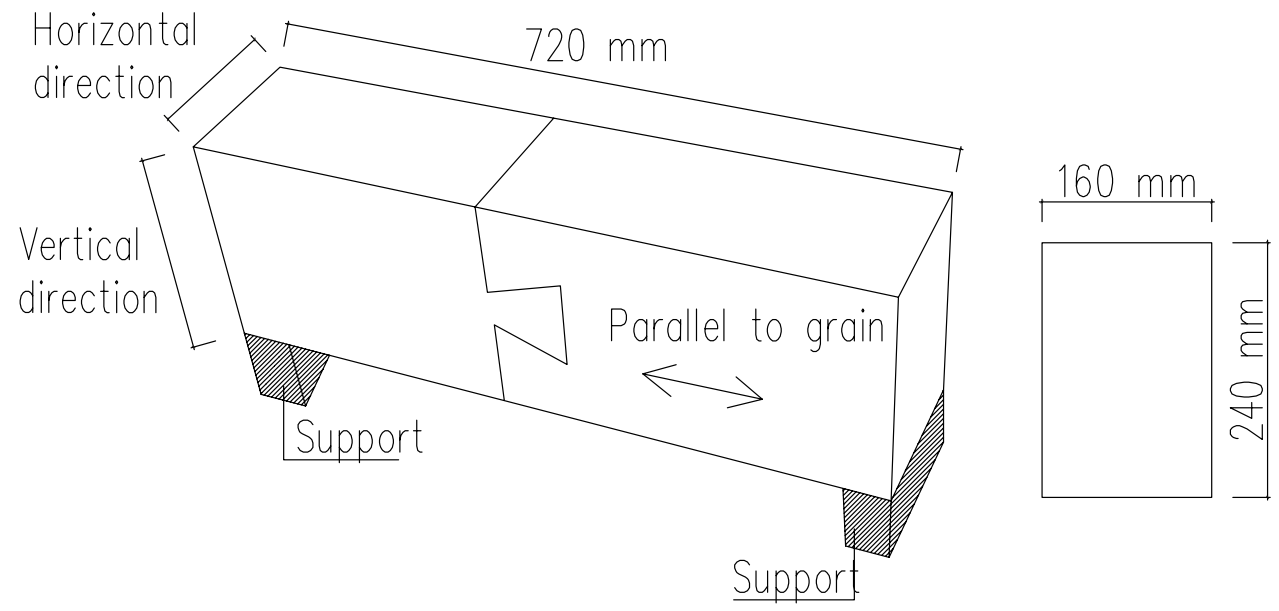



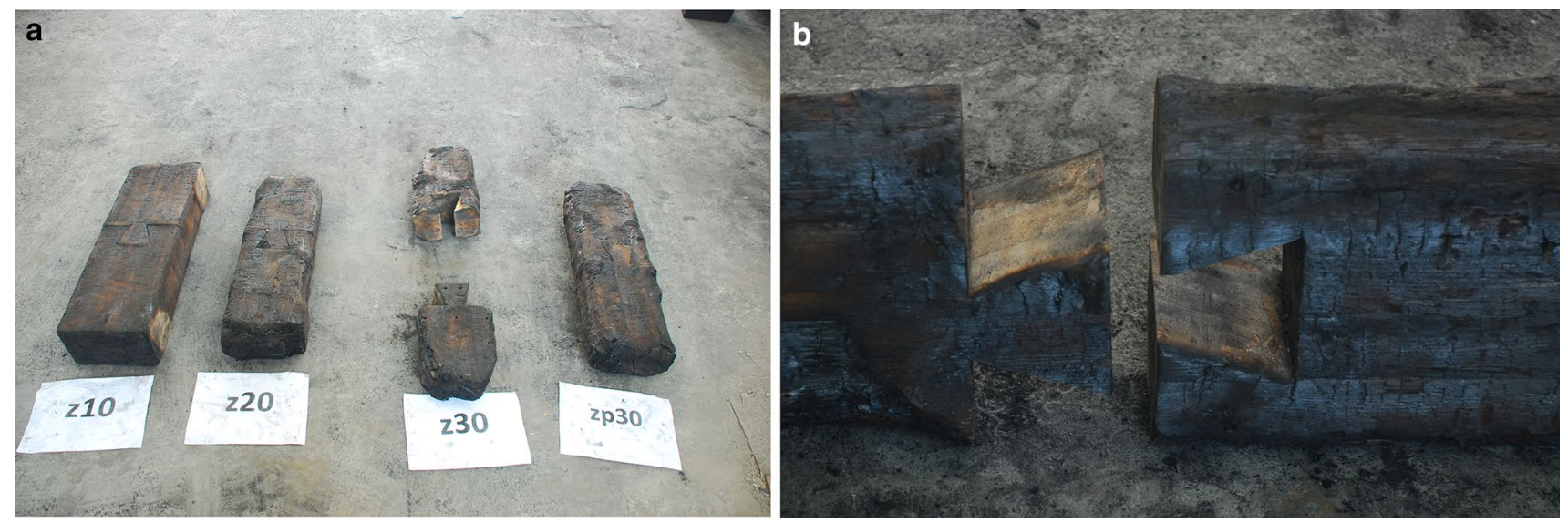

Fig. 4 Picture of specimens after fire: a comparison of different specimens after fire. b z30 after fire

Fig. 5 Furnace temperature curves of fire exposure test

Table 3 Summary of the specimen charring rates

Table 4 Converted charring rates

\begin{tabular}{|c|c|c|c|c|}
\hline \multirow[t]{2}{*}{ Number } & \multicolumn{2}{|c|}{ Charring rate $(\mathrm{mm} / \mathrm{min})$} & \multicolumn{2}{|c|}{$\begin{array}{l}\text { Converted charring rate } \\
(\mathrm{mm} / \mathrm{min})\end{array}$} \\
\hline & Horizontal & Vertical & Horizontal & Vertical \\
\hline $\mathrm{z} 10$ & 0.50 & 0.55 & 0.69 & 0.75 \\
\hline $\mathrm{z} 20$ & 0.67 & 0.70 & 0.70 & 0.73 \\
\hline z30 & 0.62 & 0.70 & 0.65 & 0.74 \\
\hline zp30 & 0.50 & 0.43 & 0.55 & 0.45 \\
\hline
\end{tabular}

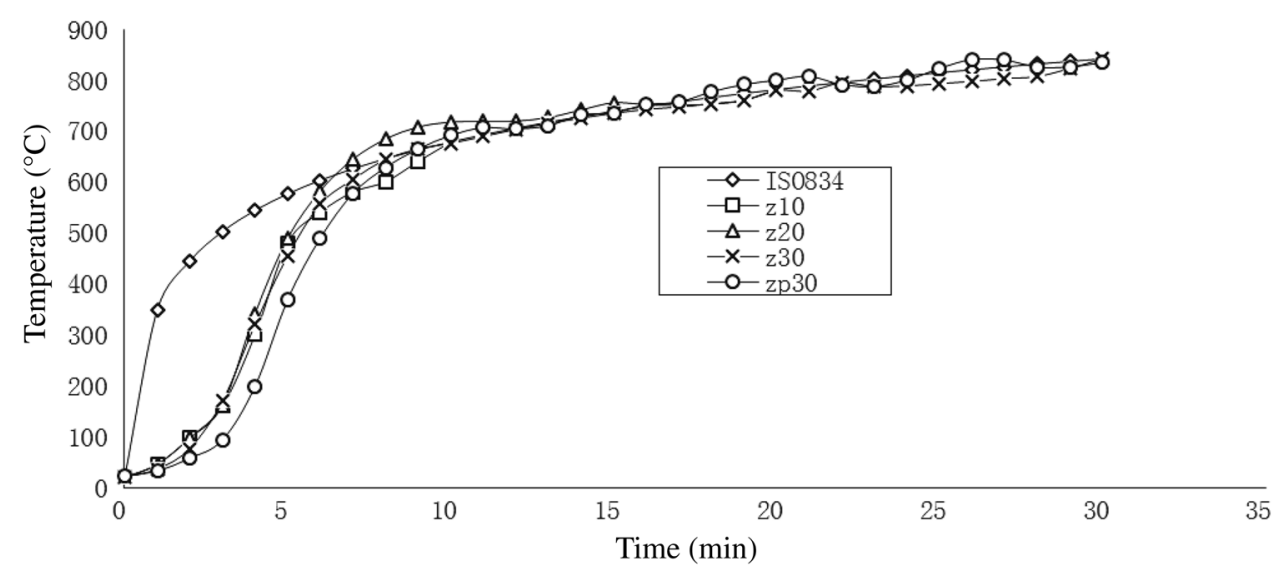

\begin{tabular}{|c|c|c|c|c|c|c|c|}
\hline \multirow[t]{2}{*}{ Number } & \multicolumn{2}{|c|}{ Original section size } & \multicolumn{2}{|c|}{ Reduced section size } & \multirow{2}{*}{$\begin{array}{l}\text { Fire expo- } \\
\text { sure time } \\
(\min )\end{array}$} & \multicolumn{2}{|c|}{$\begin{array}{l}\text { Charring rate }(\mathrm{mm} / \\
\min )\end{array}$} \\
\hline & Width (mm) & Height (mm) & Width (mm) & Height (mm) & & Horizontal & Vertical \\
\hline $\mathrm{z} 10$ & 160 & 241 & 150 & 230 & 10 & 0.50 & 0.55 \\
\hline $\mathrm{z} 20$ & 161 & 238 & 134 & 210 & 20 & 0.67 & 0.70 \\
\hline $\mathrm{z} 30$ & 160 & 241 & 123 & 199 & 30 & 0.62 & 0.70 \\
\hline zp30 & 160 & 241 & 130 & 215 & 30 & 0.50 & 0.43 \\
\hline
\end{tabular}

rate was $0.45 \mathrm{~mm} / \mathrm{min}$, both of which are smaller than the corresponding charring rates of the wood beam without the fire-retardant coating. Thus, the fire-retardant coating can efficiently extend the initial charring time of wood beams, and the fire protection effect is significant.

The original gaps between the tenon and the mortise hardly changed. The measured dimensional changes are $0-2.0 \mathrm{~mm}$, which is most likely because of drying. This result also shows that the tiny gap hardly affects the heat transfer of the specimen cross-section. The effect of the 
Table 5 List of straight-line dovetail joint specimens in the fire resistance tests

\begin{tabular}{lllll}
\hline Specimen & Specimen category & $\begin{array}{l}\text { Protective coat- } \\
\text { ing }\end{array}$ & Load level (\%) & $\begin{array}{l}\text { Number of } \\
\text { specimens }\end{array}$ \\
\hline F0 & Reference test specimen & No & - & 1 \\
F25 & Fire test specimen & No & 25 & 1 \\
F37.5 & Fire test specimen & No & 37.50 & 1 \\
F50 & Fire test specimen & No & 50 & 1 \\
FP50 & Fire test specimen & Yes & 50 & 1 \\
\hline
\end{tabular}

Fig. 6 Loading device of the tension test

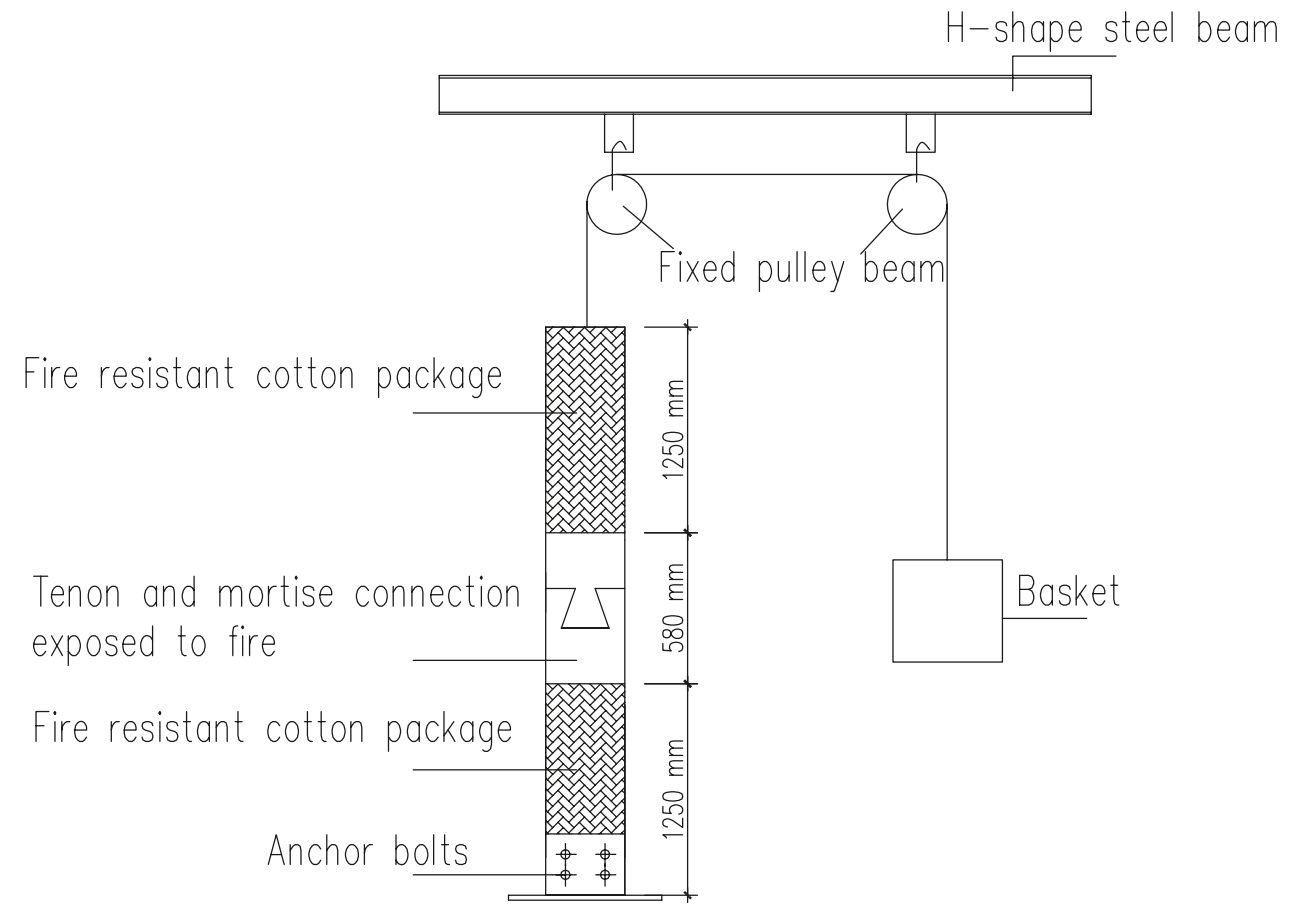

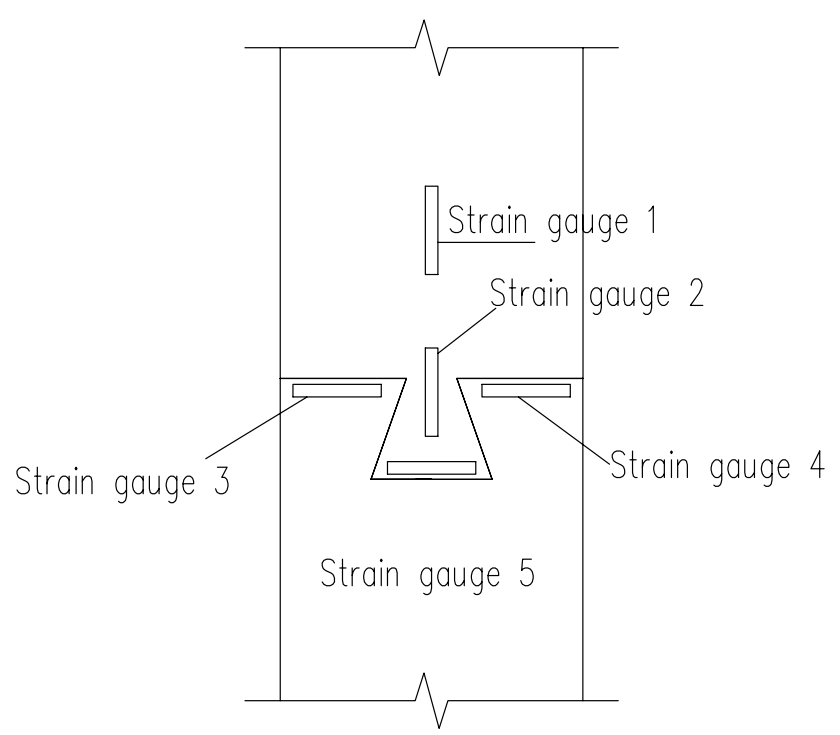

Fig. 7 Layout of the strain gauges small gap between the tenon and the mortise on the crosssection charring of the specimen was notably small.

\section{Fire resistance test and results}

\section{Test equipment and materials}

The test furnace, test material and thermocouple specifications of the fire resistance test and the results analysis were identical to those of the fire exposure test and are not repeated here.

\section{Specimens}

One straight-line dovetail joint loaded at ambient conditions was used for the reference test, and four dovetail joints exposed to a four-side fire were used for the fire tests. The load levels applied in fire were calculated as a ratio of 
Fig. 8 Failure of the straightline dovetail joint
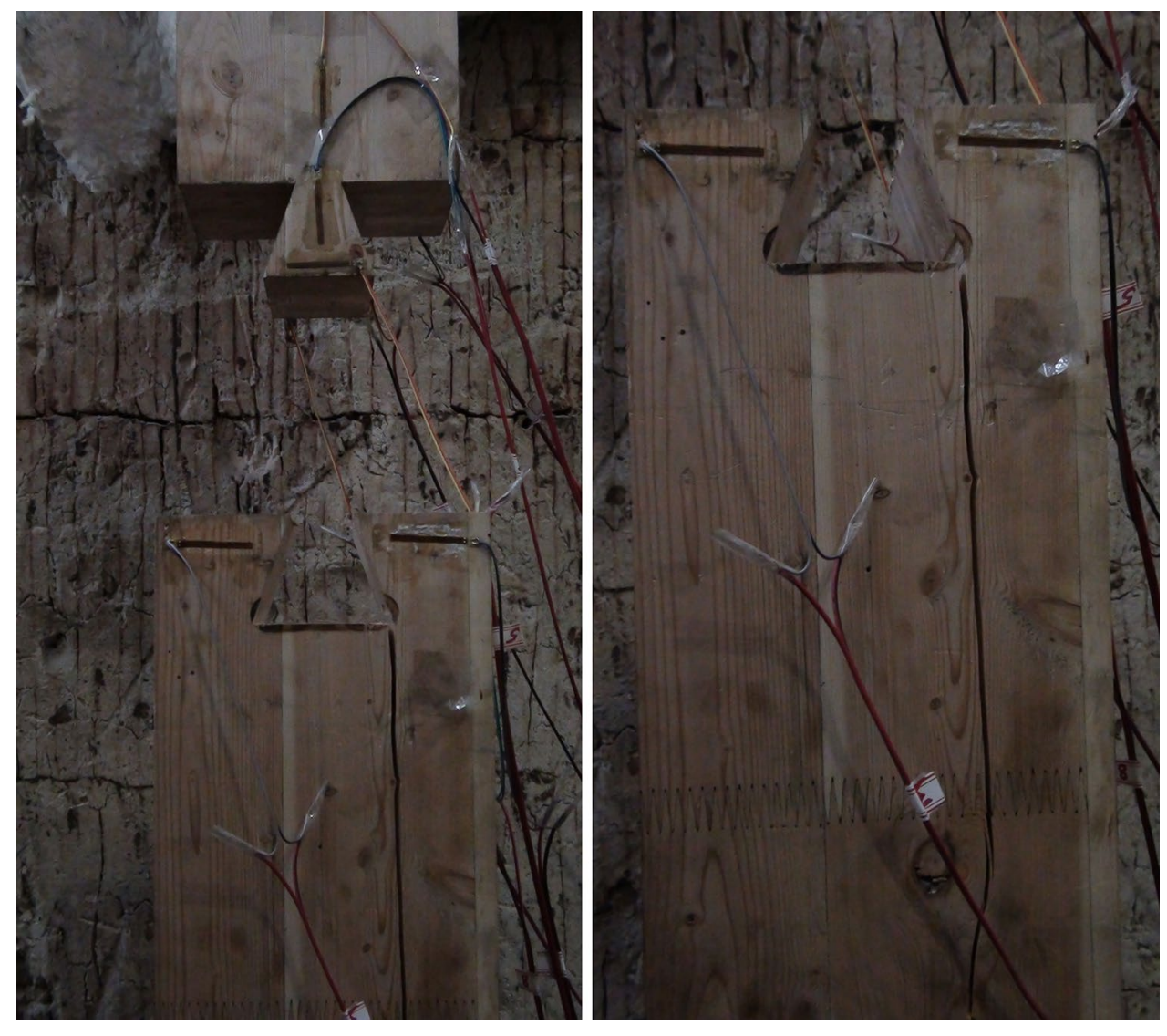

Fig. 9 Load-stress-strain curve

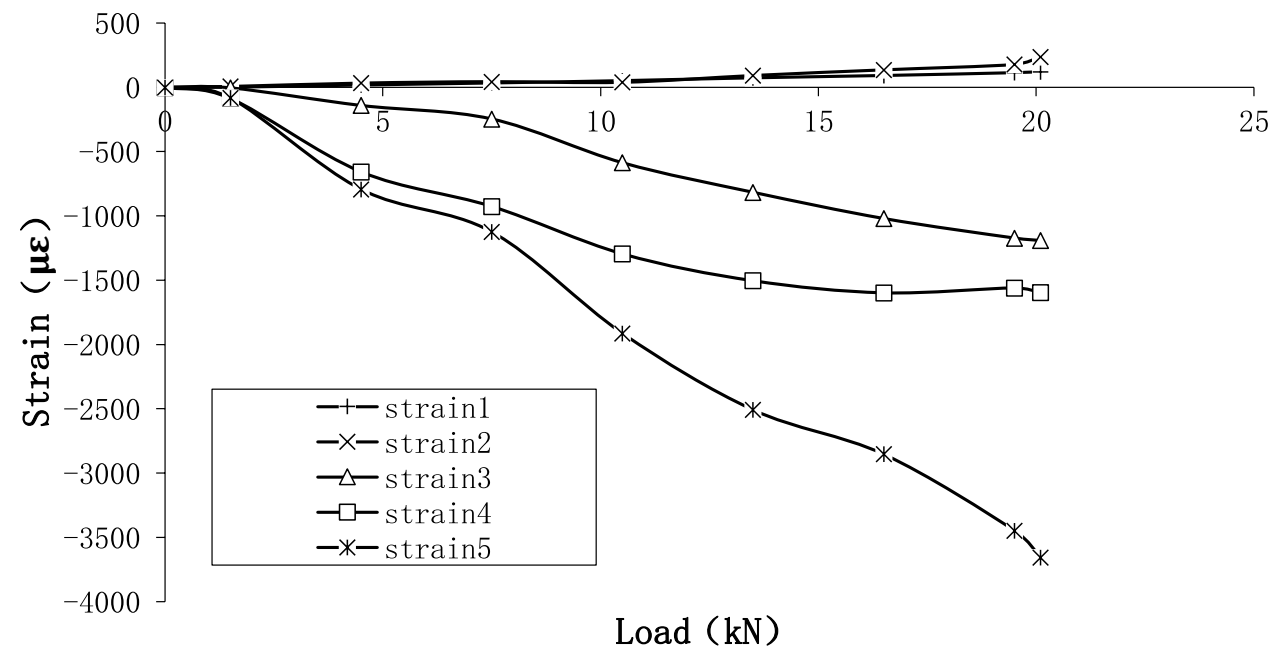

the failure load at ambient temperature. Other conditions remained identical to those in the fire exposure test. The specimen sizes of the dovetail joints are identical to those in the fire exposure test, and the numbers are shown in Table 5, where F0, F25, F37.5 and F50 represent the fire resistance test specimens which were under going $0,25,37.5$ and $50 \%$ load level, respectively, FP50 represents the fire resistance test specimen with thin film intumescent coating under going 50\% load level.

\section{Test procedures}

The fire test adopted ISO 834 [5] standard temperature rising curve. In the tests, the lower part of the straight-line dovetail joint was fixed by four anchor bolts at the bottom of the 
Fig. 10 Load-displacement curve
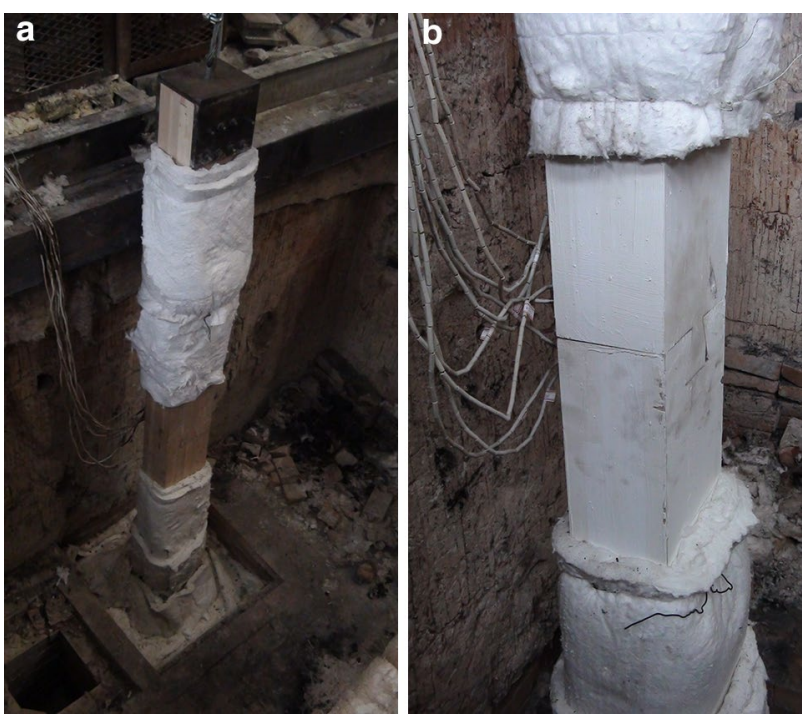

Fig. 11 Pictures of specimens before the test: a F25, b FP50

horizontal test furnace. The upper part used a mass block and a fixed pulley to maintain the straight-line dovetail joint under axial tension. The load was controlled by adding mass blocks. Each block was $0.1 \mathrm{kN}$, the displacement was read after the deformation was stable. Specimen in the reference test was unexposed to fire, and specimens in the fire test were exposed to fire. The loading device is shown in Fig. 6.

In the reference test, the specimen was first loaded to 1.5 $\mathrm{kN}$. Then, the load step was $3.0 \mathrm{kN}$. The failure criteria of the test specimens were that the straight-line dovetails could no longer hold the load.

In the fire test, the parts exposed to fire were $250 \mathrm{~mm}$ at both ends of the dovetail joint, and the left parts were unexposed. The length of the connection exposed to fire was $580 \mathrm{~mm}$. Refractory fiber cotton was used to package the unexposed parts. All four sides of the dovetail joint part were exposed to fire. The tests were carried out until the collapse of specimens that eventually fell inside the furnace.

\section{Reference test and results}

To determine the preloading of the straight-line dovetail joint in the fire test, we first performed the reference test of the straight-line dovetail joint. The displacement meter was placed at the top of the straight-line dovetail joint, and the locations of the strain gauges are shown in Fig. 7.

When the applied load was $5.0 \mathrm{kN}$, there was a slight noise and no other phenomenon on the surface. When the load was $9.0 \mathrm{kN}$, there was a continuous noise. When the load was $20.5 \mathrm{kN}$, one clear crack along the grain appeared at the mortise, and the tenon abruptly escaped from the mortise. The specimen was destroyed, as shown in Fig. 8.

Figures 9 and 10 show the load-stress-strain curve and the load-displacement curve of the straight-line dovetail joint, respectively.

In Fig. 9, strains 3, 4, and 5 are in tension, and strains 1 and 2 are in press. Figure 9 shows that (1) in the test process, the strain data of measure points 1 and 2 slightly changed, which indicates that the parallel-to-grain strain was small. (2) Because of the non-ideal axial tension and wood defects, measure points 3 and 4 were not fully symmetric, and one crack finally appeared on one side of the mortise of measure point 4 with greater strain. The tenon escaped from the mortise, and the specimen was destroyed. (3) The strain of measure point 5 almost linearly increased with the increase in load.

The load-displacement curve in Fig. 10 shows that the displacement quickly changed at the beginning of the loading possibly because the gap between the tenon and the mortise was squeezed. When the load reached $4.6 \mathrm{kN}$ and the displacement was $2.4 \mathrm{~mm}$, relationship between the displacement and force approximated linear. When the load was more than $16.8 \mathrm{kN}$ and displacement was $4.2 \mathrm{~mm}$, 

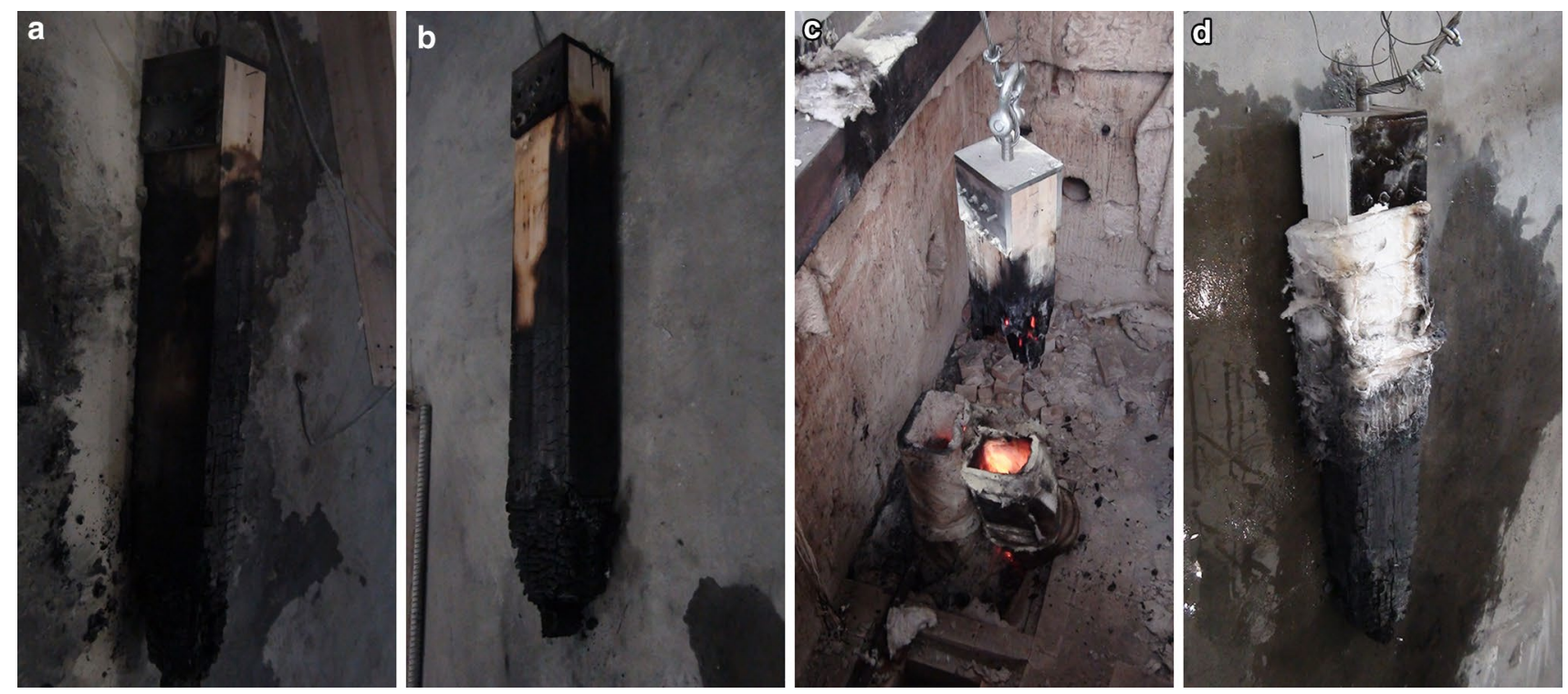

Fig. 12 Pictures of specimens after the test: a F25, b F37.5, c F50, d FP50

Fig. 13 Displacement-time curves

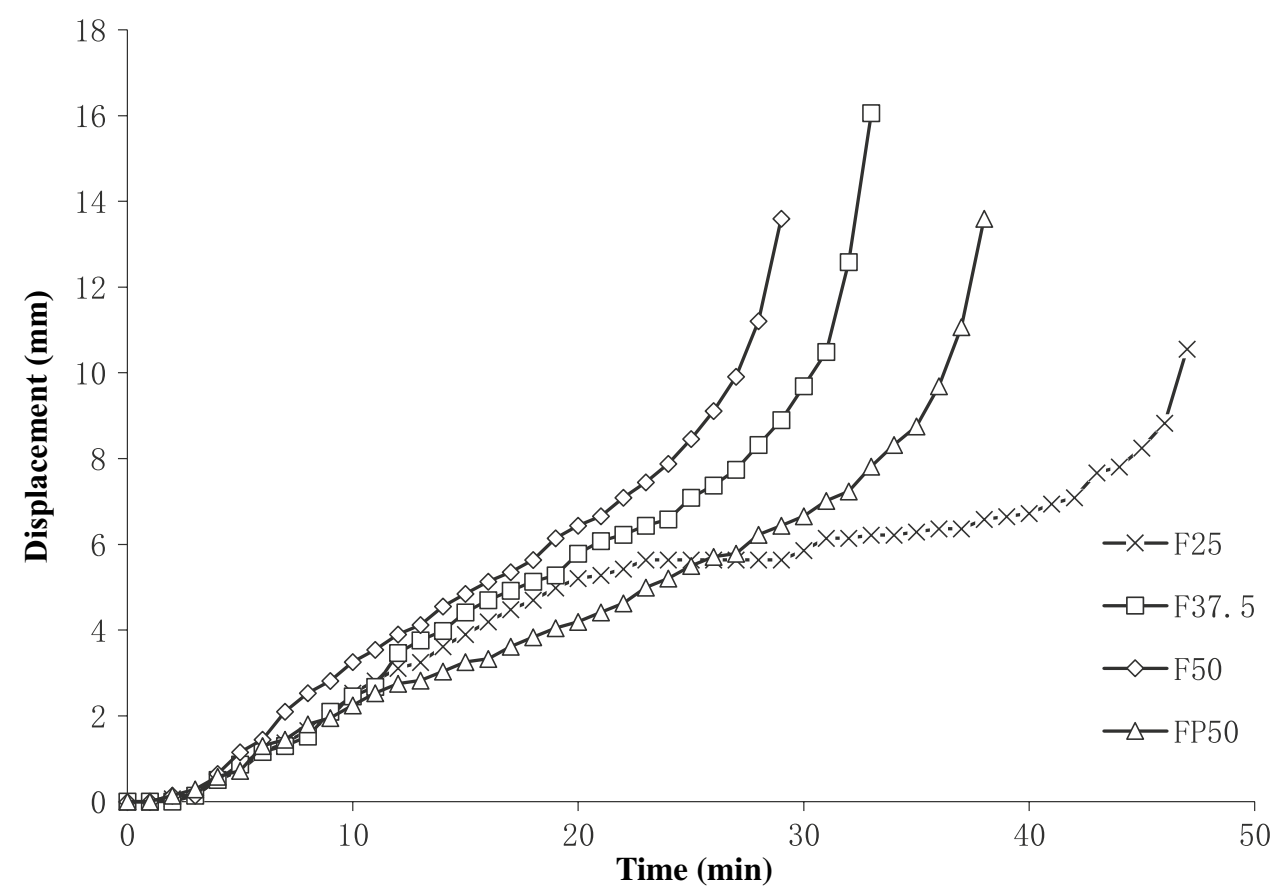

the load-displacement curve became flat and the displacement rapidly increased. When the load of the dovetail joint was maximal $(20.5 \mathrm{kN})$ and the displacement was $5.6 \mathrm{~mm}$, one longitudinal crack appeared in the parallel-to-grain direction at the mortise. Then, the tenon escaped from the mortise, and the specimen was destroyed. The last loading step is only $0.6 \mathrm{kN}$ because of sample failure.

\section{Fire test and results}

The ISO 834 [5] fire exposure was begun, and the applied load was fixed until the connection failed. F25, F37.5 and F50 with identical sizes were left unprotected. Figures 11 and 12 show the picture of the straight-line dovetail joint specimens before and after the test. All tenons were completely charred after specimens' failure.

The axial tensile deformation curve with time of the specimen in each group is shown in Fig. 13. Except for 
Fig. 14 Furnace temperature curves of fire resistance test

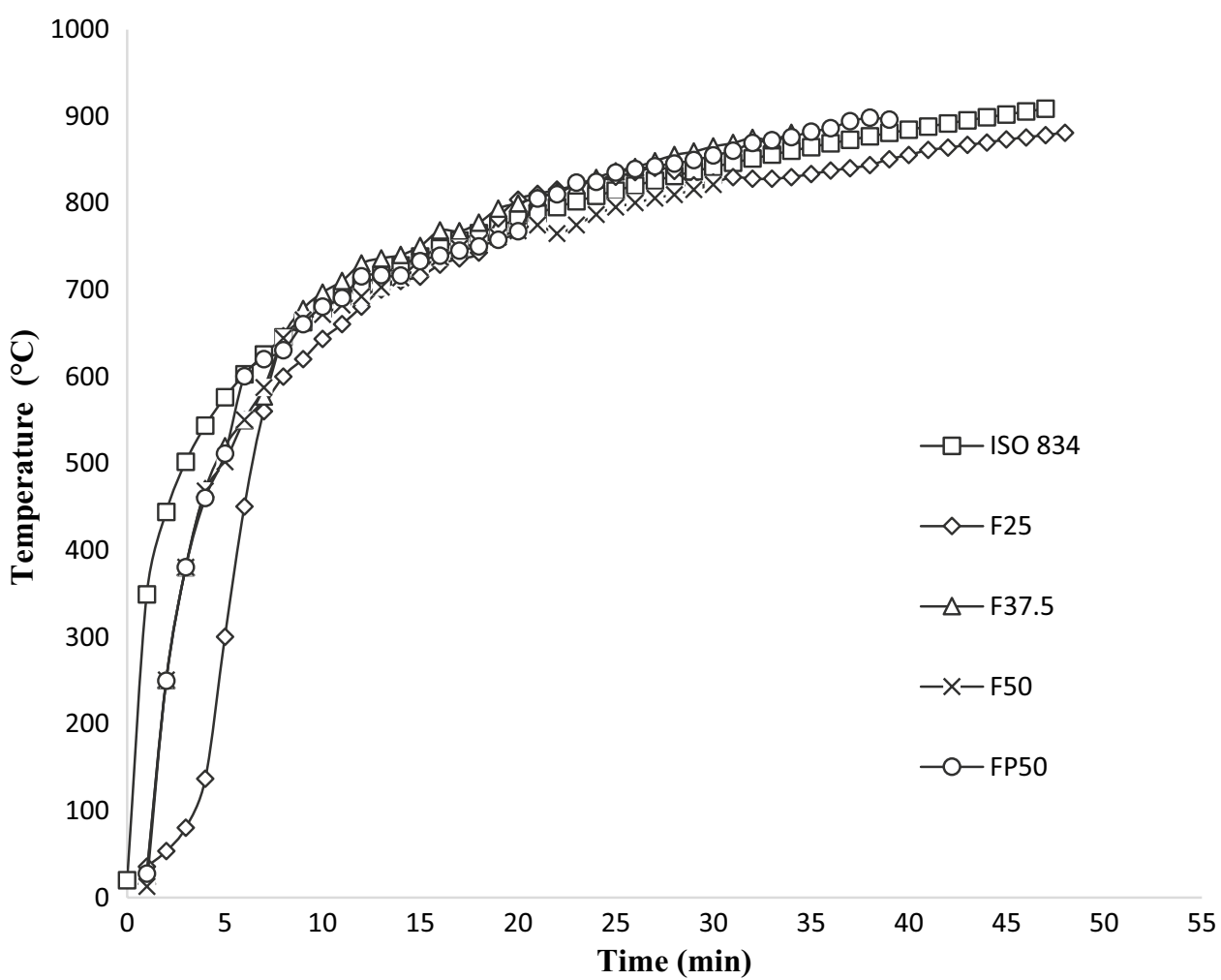

Table 6 Summary of the fire resistance experimental results of straight-line dovetail joints

\begin{tabular}{llllll}
\hline Specimen & Loading $(\mathrm{kN})$ & Load level $(\%)$ & $\begin{array}{l}\text { Protective } \\
\text { coating }\end{array}$ & $\begin{array}{l}\text { Fire resistance } \\
(\mathrm{min})\end{array}$ & $\begin{array}{l}\text { Converted fire } \\
\text { resistance }(\min )\end{array}$ \\
\hline F25 & 5.1 & 25 & No & 47 & 46 \\
F37.5 & 7.2 & 37.5 & No & 33 & 34 \\
F50 & 10.3 & 50 & No & 29 & 28 \\
FP50 & 10.3 & 50 & Yes & 38 & 38 \\
\hline
\end{tabular}

Fig. 15 Thermocouple layout map of the straight-line dovetail joints

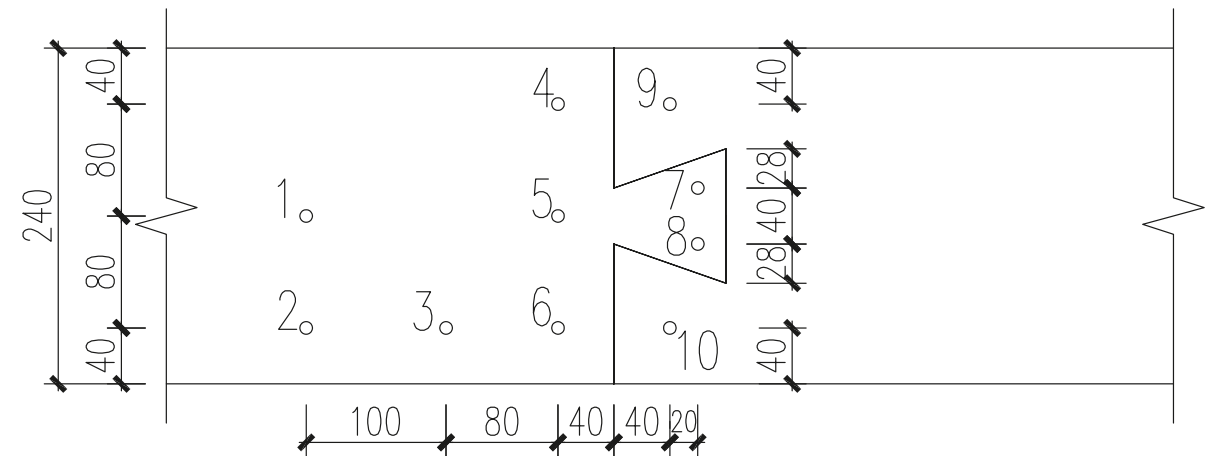

The units of size in the picture are all millimeter
F25, the furnace temperatures and the ISO 834 [5] standard temperature rising curve fit well, as shown in Fig. 14. The fire resistance experimental results are summarized in Table 6.
We observe that (1) in the dovetail joints of identical sizes, the fire resistance of the specimens decreased with the increase in load level. (2) The fire resistance of F25 was 12 min longer than that of F37.5; F37.5 lasted 6 min longer than F50. These results indicate that the effect 
Fig. 16 Temperature variation curves of z10 thermocouples: a Thermocouples \#2, \#3, \#4, \#6 and \#9. b Thermocouples \#1, $\# 5$, \#7 and \#8
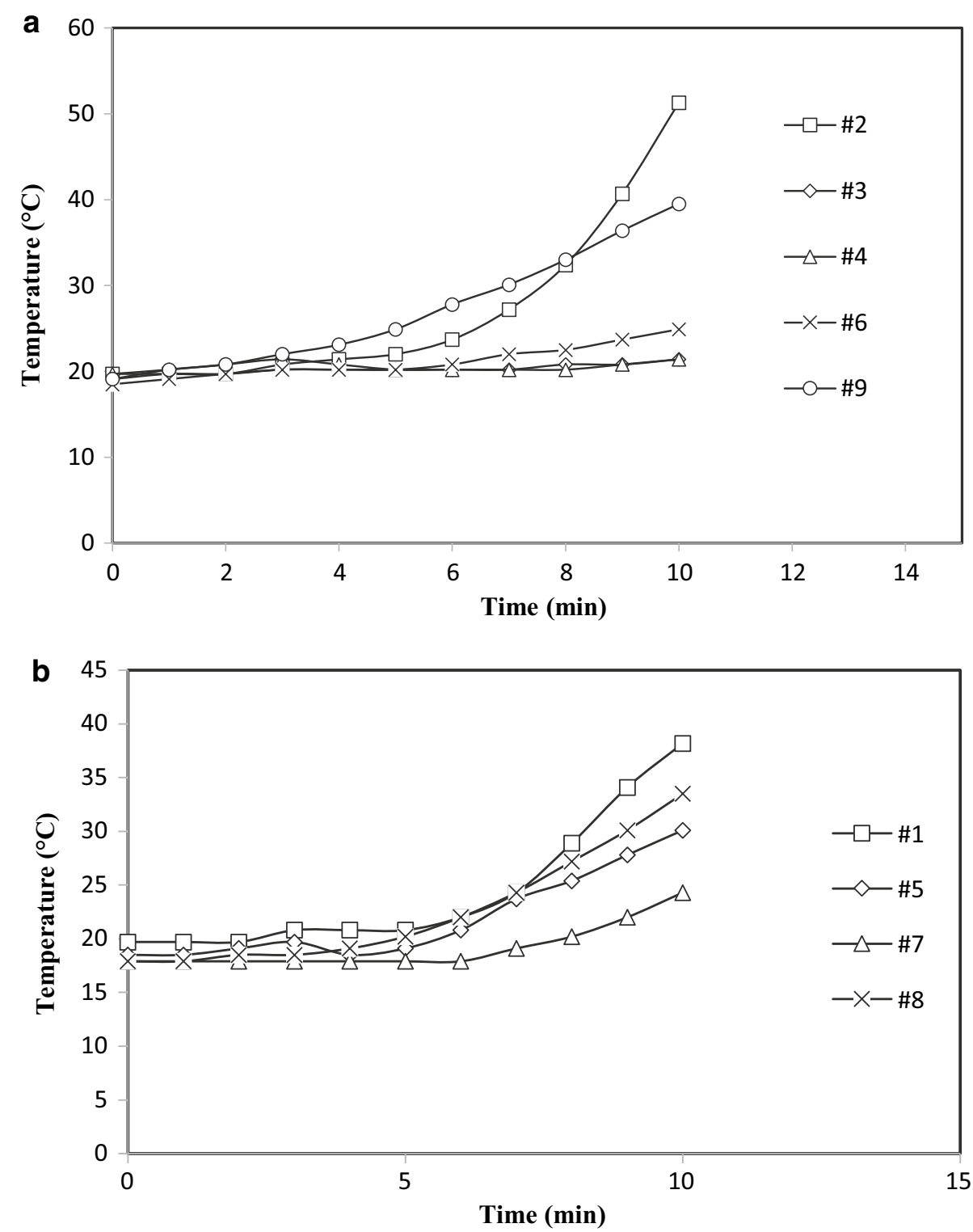

of the load level on the fire resistance of the specimen decreases with the increase in load level. The precise regulation needs further test and discussion. (3) The fire resistance of FP50 was 10 min longer than that of F50, which indicates that under identical loads, whether there is a protective coating significantly affects the fire resistance of the specimen. The protective coating can improve the fire resistance of the specimen.

\section{Cross-section temperature variation analysis}

\section{Layout of thermocouples}

The specimens were drilled to the desired depths with a $2.0 \mathrm{~mm}$ drill bit. Then, the depth of each thermocouple was marked onto it to ensure that the drilling was accurate. Figure 15 shows the thermocouple layout for all specimens. The depths of the thermocouples from the side surfaces are as follows: thermocouples 3, 4, 6, and 7 are $60 \mathrm{~mm}$ deep, and the remainder are $40 \mathrm{~mm}$ deep.

\section{Data analysis of the fire exposure test}

The temperatures of the specimens at different fire-exposure times are shown in Figs. 16, 17, 18, and 19. Because of the brittle failures of several thermocouples during the experiment, the temperature data of some thermocouples are missing.

The distances from thermocouples \#1 and \#2 to the side surface were identical. However, the distance from thermocouple \#2 to the bottom surface was $80 \mathrm{~mm}$ shorter than that 
Fig. 17 Temperature variation curves of z20 thermocouples: a Thermocouples \#4, \#9 and \#10.

b Thermocouples \#1, \#5 and \#8
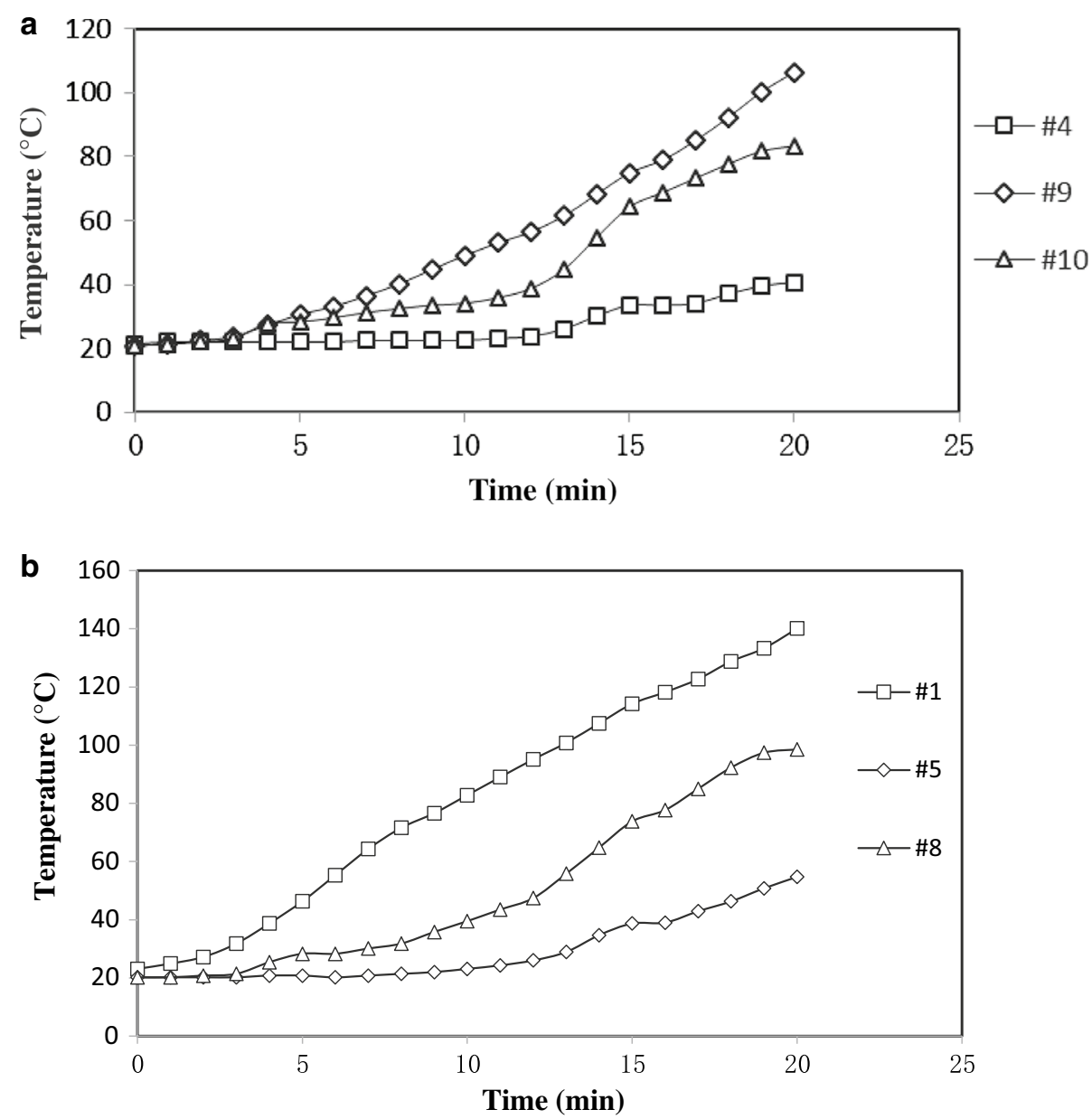

from thermocouple \#1. The temperature at thermocouple \#2 was higher than that at thermocouple \#1; with more time, the difference in temperature gradually increased. The temperature difference was $13{ }^{\circ} \mathrm{C}$ when the fuel gas was cut off, which indicates that under identical conditions, a smaller distance to the bottom surface corresponds to a higher temperature of the thermocouple.

The distances from thermocouples \#2 and \#3 to the bottom surface were identical. However, the temperature at thermocouple \#2 was higher than that at thermocouple \#3, and the temperature differences of z10 and z30 were 30 and $36^{\circ} \mathrm{C}$, respectively, when the fuel gas was cut off. This result indicates that under identical conditions, a smaller distance to the side surface corresponds to a higher temperature of the thermocouple.

Thermocouples \#5 and \#8 were compared. The distances to the bottom surface were close, and the distances to the side surface were equal. The temperature at thermocouple \#8 was slightly higher than that at thermocouple \#5. However, the maximum temperature differences of z10, z20 and z30 were 4,51 , and $61{ }^{\circ} \mathrm{C}$, respectively, when the fuel gas was cut off. The reason is that thermocouple \#8 was located at the tenon, and there was a 2-4 mm gap between the tenon and the mortise, where some heat could permeate into the internal wood. However, the maximum temperature at thermocouple \#8 of specimen z30 was $249{ }^{\circ} \mathrm{C}$, which was lower than the wood-charring temperature of $300{ }^{\circ} \mathrm{C}$. Thus, the connection of the dovetail joint was not charred.

Then, the temperature data at thermocouples \#2, \#3, \#7, and \#8 between the fire-retardant coating specimen (zp30) and the four-side fire-retardant coating specimen (z30) were compared. Because there was deviation between the furnace temperature and ISO 834 [5] temperature rising curve in the first $10 \mathrm{~min}$, as shown in Fig. 5 , the differences $\left(\Delta T_{\mathrm{n}, \mathrm{s}}\right.$, shown as the Eq. (2) below) between the furnace temperature and the thermocouple temperature were compared to eliminate the effect of deviation:

$\Delta T_{\mathrm{n}, \mathrm{s}}=T_{\text {furnace, } \mathrm{s}}-T_{\mathrm{n}, \mathrm{s}}$

where $\mathrm{n}$ represents thermocouples \#2, \#3, \#7 and \#8, s represents specimens $z 30$ and zp30. For instance, for the test of specimen $\mathrm{z} 30$, the temperature difference between furnace and thermocouple \#2 is $\Delta T_{\# 2, \mathrm{z} 30}=T_{\text {furnace, } \mathrm{z} 30}-T_{\# 2, \mathrm{z} 30}$. The results are shown in Fig. 20, which shows that after 7 min of fire exposure, the temperature difference between the furnace and the thermocouple of zp30 is more than that of $z 30$. 
Fig. 18 Temperature variation curves of z30 thermocouples: a Thermocouples \#2, \#3, \#4, \#6 and \#9. b Thermocouples \#5, $\# 7$ and \#8
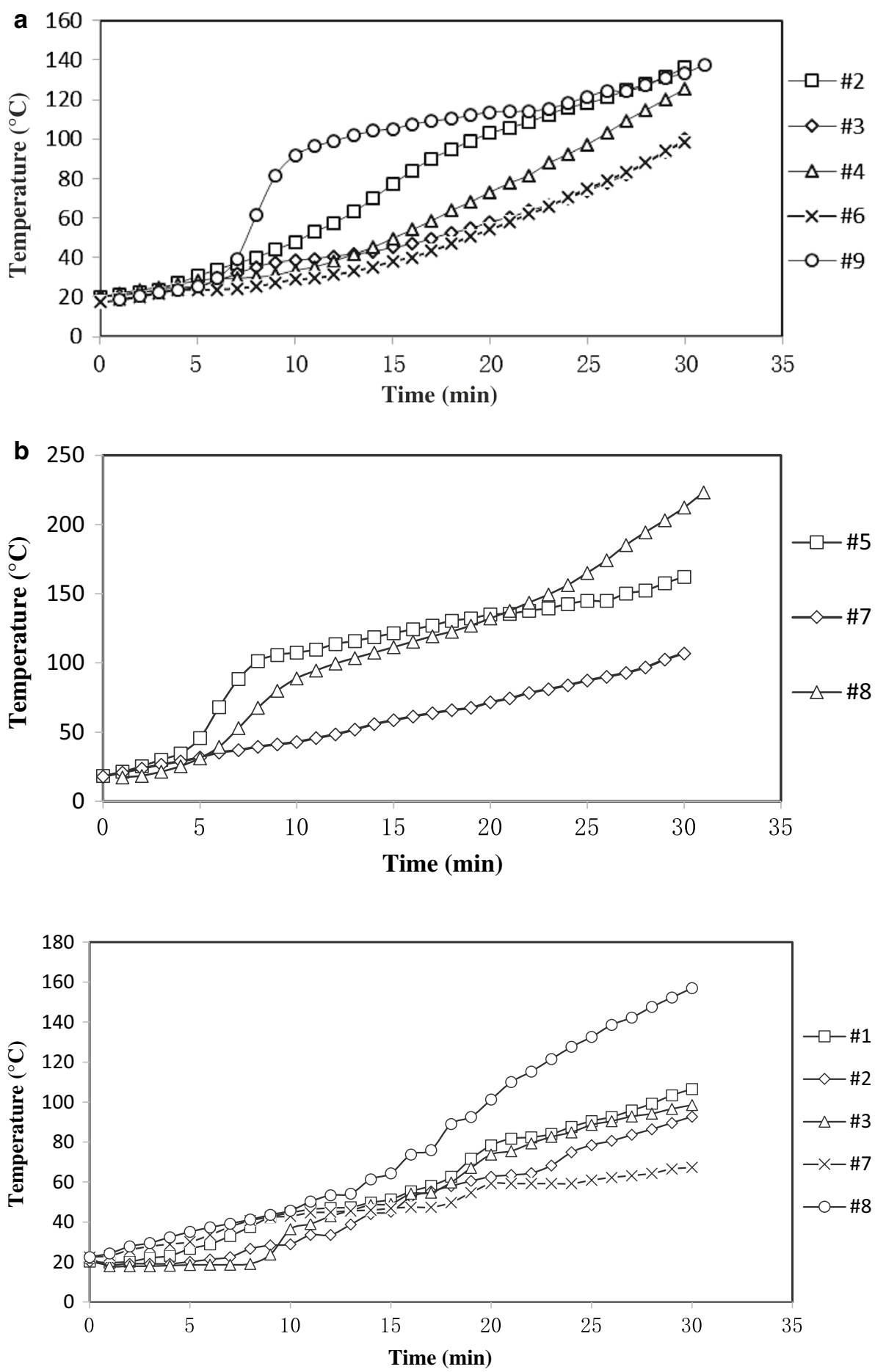

Fig. 19 Temperature variation curves of zp30 thermocouples: Thermocouples \#1, \#2, \#3, \#7 and \#8
This result indicates that the fire-retardant coating has good insulation, which further delays temperature increase.

\section{Data analysis of the fire resistance test}

In the fire resistance test, the cross-section temperature variation rules of the specimens in each group were similar to the specimen-charring rate. Thus, they are no longer listed here. Because the thermocouples were removed when the specimen failed, only the temperatures of the heating stage are shown. Because of the damage of the thermocouples in the experiment, there was only one thermocouple survived in the fire resistance test of this loaded test specimen. Expect for F25, the furnace temperatures and the ISO 834 [5] standard temperature rising curve fit well, as shown in Fig. 14. The temperature of thermocouple \#3 within unprotected 
Fig. 20 Temperature differences between the furnace and the thermocouple. $\mathbf{a} \Delta T_{\text {\#2, }, 30}$, $\Delta T_{\# 2, \mathrm{zp} 30}, \Delta T_{\# 3, \mathrm{z} 30}$ and $\Delta T_{\# 3, \mathrm{zp} 30}$. b $\Delta T_{\text {\#7, }, 30}, \Delta T_{\text {\#7, } \mathrm{zp} 30}, \Delta T_{\text {\#8, } 330}$ and $\Delta T_{\# 8, \mathrm{zp} 30}$
Fig. 21 Temperature of thermocouple \#3 within F50 and FP50
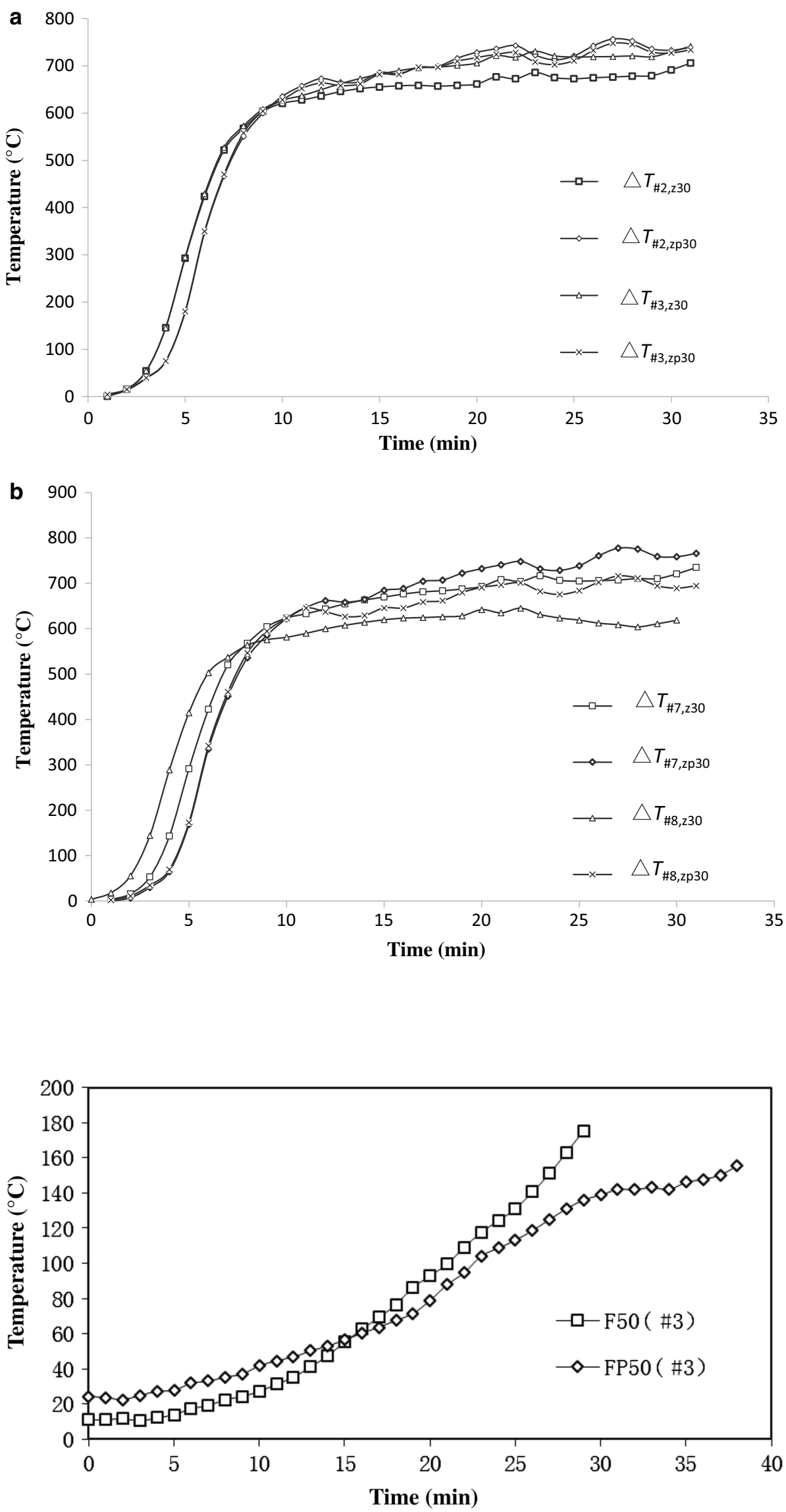
Fig. 22 Temperature differences between the furnace and the thermocouple with different load levels

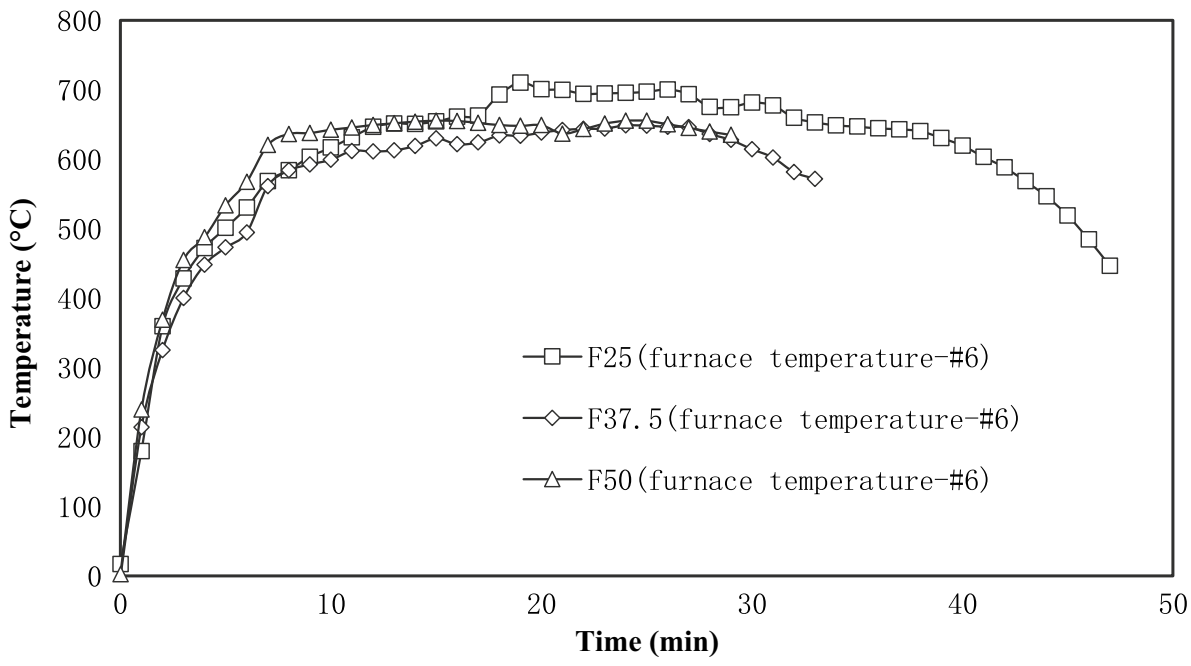

specimen F50 and protected specimen FP50 were compared. The results are shown in Fig. 21.

Figure 21 shows that although the temperature within FP50 is higher than that of F50 in the beginning, the temperatures of thermocouple \#3 within F50 is gradually larger than that of F50 after $18 \mathrm{~min}$. This result fully indicates that the fire-retardant coating has a good heat insulation effect and can well inhibit the excessively fast temperature increase of the specimen and further decrease the wood-charring rate. Finally, the fire resistance of the specimen can be improved.

To eliminate the effect of furnace temperature's deviation (F25) in the first $10 \mathrm{~min}$, the temperature differences between the furnaces of F25, F37.5 and F50 and thermocouple \#6 were compared. The results are shown in Fig. 22.

Figure 22 shows that the effects of three load levels on the temperature difference between the furnace and measuring point \#6 had no significant laws, which indicates that the structure field has few effects on the temperature field at this measuring point.

\section{Conclusion}

This paper presents the result of fire tests on straight-line dovetail joints. The experiment includes fire exposure and fire resistance tests of protected and unprotected dovetail joints. The specimen with protective coating had longer fire resistance than the unprotected specimen. The primary observations are reported here. Due to the limited funding, one specimen in each test was studied, and more specimens should be tested in the following tests:

1. There was a gap between the tenon and the mortise in the straight-line dovetail joint. The gap was hardly charred, and the charring rate was almost zero. The effect of the heat transfer of the tiny gap in the dovetail joint can be neglected.

2. The dovetail joint with fire-retardant coating had a smaller mean charring rate than the dovetail joint without fire-retardant coating. This result indicates that the fire-retardant coating can efficiently delay the temperature increase of the dovetail joint, and the fire protection effect is significant.

3. Only one thermocouple survived in the fire resistance test due to the damage of other thermocouples. The fire resistance of the specimen decreased with the increasing load level. The fire resistance of F25 lasted $12 \mathrm{~min}$ longer than that of F37.5, and F37.5 lasted 6 min longer than F50. With the increasing load level, the effect of the load level on the fire resistance of the specimen decreased. At identical load levels, the fire resistance values of the protected and unprotected specimens are $38 \mathrm{~min}$ and $28 \mathrm{~min}$, respectively. The protective coating can improve the fire resistance of the specimen.

4. The temperature comparison of specimens with different load levels at identical measuring points shows that the load level does not significantly affect the speed of temperature increase, which means the load level does not significantly affect the distribution of temperature field.

Funding This work was supported by the National Natural Science Foundation of China (Grant no. 51178115) and a Project Funded by the Priority Academic Program Development of Jiangsu Higher Education Institutions (PAPD).

\section{References}

1. Bisby LA, Frangi A (2015) Special issue on timber in fire. Fire Technol 51:1275-1277 
2. Friquin KL (2011) Material properties and external factors influencing the charring rate of solid wood and glue-laminated timber. Fire Mater 35:303-327

3. EN (2004) Eurocode 5: design of timber structures-part 1-2: general-structural fire design (British Standards). European Committee For Standardization, Brussels

4. Hugi E, Wuersch M, Risi W, Ghazi Wakili K (2007) Correlation between charring rate and oxygen permeability for 12 different wood species. J Wood Sci 53:71-75

5. ISO 834-1 (1999) Fire resistance tests: elements of building construction. Part 1: general requirements. International Organization for Standardization, Geneva, p 12

6. Njankouo JM, Dotreppe JC, Franssen JM (2005) Fire resistance of timbers from tropical countries and comparison of experimental charring rates with various models. Constr Build Mater 19:376-386

7. Firmanti A, Subiyanto B, Takino S, Kawai S (2004) The critical stress in various stress levels of bending member on fire exposure for mechanical graded lumber. J Wood Sci 50:385-390

8. Babrauskas V (2005) Charring rate of wood as a tool for fire investigations. Fire Safety J 40:528-554

9. Norén J (1996) Load-bearing capacity of nailed joints exposed to fire. Fire Mater 20:133-143

10. Peng L, Hadjisophocleus G, Mehaffey J, Mohammad M (2011) Predicting the fire resistance of wood-steel-wood timber connections. Fire Technol 47:1101-1119

11. Audebert M, Dhima D, Taazount M, Bouchair A (2011) Numerical investigations on the thermo-mechanical behavior of steel-totimber joints exposed to fire. Eng Struct 33:3257-3268

12. Audebert M, Dhima D, Taazount M, Bouchair A (2014) Experimental and numerical analysis of timber connections in tension perpendicular to grain in fire. Fire Saf J 63:125-137
13. Zhang J, Liu Z, Xu Y, Ma S, Xu Q (2012) An experimental and numerical study on the charring rate of timber beams exposed to three-side fire. Sci China Technol Sci 55:3434-3444

14. Zhang J, Xu Q, Xu Y, Wang B, Shang J (2012) A numerical study on fire endurance of wood beams exposed to three-side fire. J Zhejiang Univ Sci A 13:491-505

15. Xu Q, Li X, Mu B, Zhang J, Xu M, Li S (2011) Static experimental research on mechanical behavior of timber beams with lime putty finishing after fire (in Chinese). J Build Struct 32:73-79

16. Ni Z, Peng L, Qiu P, Zhang H (2012) Experimental study on fire resistance performance of timber assemblies (in Chinese). China Civil Eng J 45:108-114

17. Ru H, Liu W, Lu W, Yang H (2011) Fire resistance experiment on bolted connections in glued laminated timber (in Chinese). $\mathrm{J}$ Nanjing Univ Technol (Natural Science Edition):70-74

18. Ogawa K, Sasaki Y, Yamasaki M (2016) Theoretical estimation of the mechanical performance of traditional mortise tenon joint involving a gap. J Wood Sci 62:242-250

19. Kunecky J, Arciszewska-Kedzior A, Sebera V, Hasnikova H (2016) Mechanical performance of dovetail joint related to the global stiffness of timber roof structures. Mater Struct 49:2315-2327

20. Li XW, Zhao JH, Ma GW, Huang SH (2015) Experimental study on the traditional timber mortise-tenon joints. Adv Struct Eng 18:2089-2102

21. Frangi A, Fontana M (2003) Charring rates and temperature profiles of wood sections. Fire Mater 27:91-102

22. Buchanan AH (2001) Structural design for fire safety. Wiley, UK

23. Drysdale D (1998) An introduction to fire dynamics. John Wiley \& Sons, UK, p 399 